\title{
Correction to: Atmospheric Aerosols: Some Highlights and Highlighters, 1950 to 2018
}

\author{
G. M. Hidy ${ }^{1}$
}

Published online: 26 April 2019

(c) The Author(s) 2019, corrected publication 2019

\section{Correction to: \\ Aerosol Science and Engineering (2019) 3:1-20 https://doi.org/10.1007/s41810-019-00039-0}

The article "Atmospheric Aerosols: Some Highlights and Highlighters, 1950 to 2018 " written by G. M. Hidy was originally published electronically on the publisher's internet portal (currently SpringerLink) on 23 February 2019 without open access.

After publication in volume [3], issue [1], page [1-20] with the author(s)' decision to opt for Open Choice the copyright of the article changed on April 2019 to (C) The Author(s) 2019 and the article is forthwith distributed under the terms of the Creative Commons Attribution 4.0 International License (http://creativecommons.org/licenses/ by/4.0/), which permits use, duplication, adaptation, distribution and reproduction in any medium or format, as long as you give appropriate credit to the original author(s) and the source, provide a link to the Creative Commons license, and indicate if changes were made.

The original article has been corrected.

Open Access This article is distributed under the terms of the Creative Commons Attribution 4.0 International License (http://creativeco mmons.org/licenses/by/4.0/), which permits unrestricted use, distribution, and reproduction in any medium, provided you give appropriate credit to the original author(s) and the source, provide a link to the Creative Commons license, and indicate if changes were made.
The original article can be found online at https://doi.org/10.1007/ s41810-019-00039-0.

\section{G. M. Hidy}

ghidy113@gmail.com

1 Envair/Aerochem, Placitas, NM, USA 